\title{
An Analysis of Pre-Service Teachers' Lesson Plan
}

\section{Masfa Maiza}

Pamane Talino College of Education masfamaiza27@gmail.com

\section{Info Artikel}

Sejarah Artikel:

Diterima Agustus 2019

Disetujui September 2019

Dipublikasikan September 2019

\begin{abstract}
Abstrak
Rencana Pelaksanaan Pembelajaran (RPP) adalah salah satu bagian penting dalam proses pembelajaran dengan tujuan untuk memberikan instruksi di dalam kelas. Penelitian ini bertujuan untuk mengidentifikasi aspek-aspek RPP Kurikulum 2013 yang disusun oleh para calon guru. Penelitian ini merupakan penelitian deskriptif kualitatitf. Sejumlah sepuluh RPP dari lima calon guru dianalisis menggunakan analisis dokumen dengan teori dari Brown (2001), di antaranya yaitu tujuan, indikator, materi dan sumber belajar, langkah-langkah pembelajaran dan penilaian. Hasil penelitian menujukkan bahwa para calon guru sudah bagus dalam menyusun tujaun pembelajaran, materi dan sumber belajar dan langkah-langkah pembelajaran, namun mereka masih harus meningkatkan kemampuan dalam menyusun indikator dan penilaian. Oleh karena itu, dapat disimpulkan bahwa para calon guru telah mampu menyusun RPP mata pelajaran Bahasa Inggris berdasarkan karakteristik pada Kurikulum 2013.
\end{abstract}

Kata Kunci: Rencana Pelaksanaan Pembelajaran, Kurikulum 
procedure, but they should improve their ability in creating objectives and evaluation. In short, they are able to design English lesson plans based on its characteristics of 2013 curriculum.

Keywords: lesson plan, curriculum

ISSN 2580-6335 (online)

ISSN 2461-3961 (cetak)

\section{INTRODUCTION}

Indonesia applies 2013 curriculum for learning process since 2013. This curriculum has been developed from the previous, namely School Based Curriculum (Kurikulum Tingkat Satuan Pendidikan). In order to accommodate the implementation of 2013 Curriculum, lesson plan is needed to arrange. Nesari and Heidari (2014) have an overview of lesson plan that by having lesson plan, a teacher is able to manage time, effort and resources efficiently. It means that lesson plan can be as guidance for teachers to carry out the learning process systematically.

According to Minister of National Education Regulation number 22 Year 2016, lesson plan is described as a plan for one meeting or more. The teachers should arrange the lesson plan in order to gain the basic competence provided in syllabus. Yet, it is also stated that designing lesson plan should be based on the characteristics of students, students' participation, students centered, development of reading and writing, feedback, and integrated with communication and information technology.

Referring to the arrangement of lesson plan, each school should have different lesson plan in some principals as mentioned above. This also involves the role of teachers or preservice teachers. Teachers will easily analyze the characteristics of lesson plans based on their schools, but it will be different with preservice teachers. This study focuses on preservice teachers in designing lesson plan.

Before designing lesson plan, the component of core competence and basic competence in 2013 curriculum should be mastered first. The basic competence will show the point in completing each components of lesson plan. Here, pre-service teachers of Pamane Talino College of
Education who haven't learned about that also have responsibility to design a correct lesson plan. They join a teaching program at schools in three months after having microteaching and curriculum, material and development subjects in the previous semester.

In accordance with the implementation of 2013 curriculum, this research explores the process of how pre-service teachers prepare for designing lesson plan. Those pre-service teachers have their experience in teaching program. Thus, this aims to analyze preservice teachers' lesson plan that can meet demands of 2013 curriculum.

\section{THEORITICAL REVIEW}

According to enclosure of Minister of National Education Regulation Number 59 Year 2014, 2013 curriculum is one of the government's efforts to resolve the various problems being faced by the education today. Its characteristics appears in (1) developing attitudes, knowledge and skills, (2) developing the competencies expressed in core competencies and specified more in basic competencies, (3) developing class core competence into organizing elements of basic competence and (4) developing a basic competence based on the accumulative principle.

The implementation of 2013 curriculum is using a scientific approach. It is expected to produce a productive, creative and innovative human and it is implemented in three dimensions of teaching learning planning, teaching and learning process and learning evaluation. One of those dimensions which is discussed in this study is teaching learning planning called lesson plan.

Brown (2001) describes lesson plan as a set of activities which represents steps 
along a curriculum before which and after which you have a hiatus (a day or more) in which to evaluate and prepare for the next lesson. It also explains lesson plan as a set of activities that cover a period of classroom time. The followings are the elements of a lesson plan:

1. Goal(s); it identifies an overall purpose or goal to accomplish by the end of the class period.

2. Objectives; it is very important to state explicitly what the teachers want students to gain from the lesson. It also states what students will do. It is also important to state the objectives using Bloom's Taxonomy and three domains of academic learning: cognitive, affective and psychomotor. The cognitive domain includes mental skill to produce knowledge; the affective domain adds gradual emotional development of attitude; whereas the psychomotor domain encompasses physical skills (Bloom, 1956).

3. Materials and equipment; a list of materials is needed and also good planning includes what the teachers take to arrange or have in the classroom.

4. Procedures; it includes an opening or activity as a warm-up, a set of activities and techniques in appropriate proportions and closure.

5. Evaluation; it determines the objectives which have been accomplished although it does not need to end with a little quiz, nor does evaluation need to be a separate element.

As cited in Sesiorina (2014), her study concludes that teachers are able implement the characteristics which are 'exposing vocabulary items', 'exposing oral production' and 'showing teacher's regular monitoring" into their English lesson plans. Those gain to the aspects of designing lesson plan in which Harmer (2007) highlights two important points. First, lesson plan is a guide for teachers which needs creative changes to adapt till the end of the lesson. Second, it relates to teacher's relationship with students in which the commitment towards teaching will lead the students to give teachers positive responds.

\section{METODE}

This research used qualitative method. Theory from Brown (2001) was used to analyze the data. It analyzed ten English lesson plans by five pre-service English teachers. Those pre-service teachers were from Pamane Talino College of Education, Landak Regency, West Kalimantan who had finished teaching practice program at schools in three months. They taught in different schools categorized as public senior high school in a town, private senior high school in a town, public senior high school in a district, private senior high school in a district and private senior high school in a remote area. This study used document analysis. Thus, those lesson plans were analyzed based on goals, objectives, materials and equipment, procedures and evaluation.

Table 1. Rubric to analyze lesson plan

\begin{tabular}{|l|l|}
\hline Aspects & Characteristics \\
\hline Goal & Achievable \\
\hline Objectives & Congruent with goals \\
\hline $\begin{array}{l}\text { Materials and } \\
\text { Equipment }\end{array}$ & $\begin{array}{l}\text { Effective, appropriate } \\
\text { and practical }\end{array}$ \\
\hline Procedure & In line with objectives \\
\hline Evaluation & $\begin{array}{l}\text { Congruent with } \\
\text { objectives } \\
\text { procedures }\end{array}$ \\
\hline
\end{tabular}

\section{RESULT AND DISCUSSION}

Pamane Talino College of Education is located at Landak Regency, a less-developed area in West Kalimantan, Indonesia. One of the subjects in the curriculum is teaching practice program. It is held in three months and the students are distributed into several senior high schools at Landak Regency. Then the students who have finished their teaching practice program called pre-service teachers. Although they do not fully teach, they have chances to learn how to design a lesson plan based on the implementation of 2013 curriculum. At last, they produce lesson plans which are congruent with the school characteristics.

As 10 lesson plans of English lesson were analyzed in five aspects of goals, objectives, materials and equipment, procedure and evaluation, the results of this analysis are shown as the followings: 
1. Goals

The findings of this study show that the goals were achievable for senior high school learners. Based on the basic competence, all of the lesson plans use Bloom's taxonomy namely remembering and understanding.

2. Objectives

The objectives consist of Audience, Behavior, Condition, and Degree (ABCD). They also cover three learning domains of cognitive, affective and psychomotor. The features of $\mathrm{ABCD}$ can be seen as follows:

a. In the end of the lesson $(\mathrm{C})$, students (A) are able to introduce their self (B) using correct pronunciation (D).

b. After being shown pictures (C), students (A) are able to write a passive sentence (B) correctly (D).

c. In the end of the lesson (C), students (A) are able to read an announcement (B) using correct pronunciation (D).

In contrast, some objectives also miss the features of $\mathrm{ABCD}$, for example:

a. The students (A) are able to introduce their self (B) correctly (D).

b. In the end of the lesson (C), students (A) are able to write passive voice (B).

c. The students (A) are able to read an announcement (B).

The element of objectives also provides three learning domains. The most frequent only comes to cognitive domain as the objectives state. The example of affective domain appears on the students' cooperative. Psychomotor domain can be seen from the learning process through games.

3. Materials and Equipment

The following table shows the materials and equipment stated in ten lesson plan.

Table 2. Materials and Equipment Used

\begin{tabular}{|l|l|}
\hline Materials & Equipment/Media \\
\hline Self-introduction & Audio-visual \\
\hline Recount text & Word wall \\
\hline Announcement & Game \\
\hline Narrative text & Picture series and \\
\hline
\end{tabular}

\begin{tabular}{|l|l|}
\hline & story telling \\
\hline Song & Audio \\
\hline
\end{tabular}

The use of equipment is much needed in order to engage the students for learning process. More varied kinds of media can accommodate and improve the students' ability. Moreover, the students in this less-developed area need more attention. From the result of lesson plan, the materials and equipment are effective, appropriate and practical.

4. Procedures

The procedures refer to the activities in the learning process. The sequence activities of learning based on 2013 curriculum consist of five activities, namely observing, questioning, exploring, associating and communicating. The procedures shown in the lesson plan also congruent with the implementation of methods or media. In addition, the teachers also demonstrate their role in giving feedback, support and motivation.

5. Evaluation

The evaluation designed utilizes the activity based on the objectives. It measures the objectives not only for individual evaluation but also in groups. Yet, most of the evaluation is made for individual task.

Here is the example of evaluation made:

Table 3. Design of Evaluation 1

\begin{tabular}{|l|l|l|}
\hline Objective & Activity & Evaluation \\
\hline Introduce & Speaking & $\begin{array}{l}\text { Introduce } \\
\text { yourself ....! }\end{array}$ \\
\hline Write & Writing & $\begin{array}{l}\text { Write down } \\
\ldots !\end{array}$ \\
\hline Read & Reading & $\begin{array}{l}\text { Read the } \\
\text { announcement } \\
\text { loudly! }\end{array}$ \\
\hline Retell & Speaking & $\begin{array}{l}\text { Retell the } \\
\text { story in group } \\
\ldots !\end{array}$ \\
\hline Identify & Listening & $\begin{array}{l}\text { Fill in the } \\
\text { blanks ...! }\end{array}$ \\
\hline
\end{tabular}

On the other hand, it is also found that the evaluation does not match to the objectives.

Table 4. Design of Evaluation 2

\begin{tabular}{|l|l|l|}
\hline Objective & Activity & Evaluation \\
\hline Read & Reading & Write down \\
\hline
\end{tabular}




\begin{tabular}{|l|l|l|}
\hline & & $\ldots !$ \\
\hline Retell & Speaking & $\begin{array}{l}\text { Write down a } \\
\text { story ...! }\end{array}$ \\
\hline Identify & Listening & $\begin{array}{l}\text { Mention the } \\
\text { songs ... ! }\end{array}$ \\
\hline
\end{tabular}

\section{CONCLUSION}

The findings from this study show that the pre-service teachers are able to design English lesson plans in which all five aspects are included. They realize the importance of designing lesson plan correctly since it will be as their guidance to teach in the classroom. The aspect is started from goals in which their goals are measurable. The materials are also based on basic competence with varied kinds of methods or media and their procedures also show the implementation of 2013 curriculum. However, the ability of creating the objectives of learning should be improved. Some are still lack in writing the element of ABCD (Audience, Behavior, Condition, and Degree) and the frequent of affective and psychomotor learning domain. Besides, the elements of evaluation also should be mastered well. Regarding the aspects of lesson plan, it can be concluded that pre-service teachers at Pamane Talino College of Education could design English lesson plans based on its characteristics of 2013 curriculum.

\section{REFERENCES}

Anderson, L., \& Krathwohl, D. A. (2001). Taxonomy for Learning, Teaching and Assessing: A Revision of Bloom's Taxonomy of Educational Objectives. New York: Longman

Brown, H. D. (2001). Teaching by Principles: An Interactive Approach to Language Pedagogy $2^{\text {nd }}$ Edition. New York: Addison Wesley Longman, Inc.

Harmer, J. (2007). The Practice of English Language Teaching $4^{\text {th }}$ Edition. Harlow: England Pearson Education.

Minister of National Education Regulation Number 59 Year 2014 about 2013 Curriculum for Senior High School.
Minister of National Education Regulation Number 22 Year 2016 about Standard of Process for Primary and Secondary Education.

Nesari, A. J.and Heidari, M. (2014). The Important Role of Lesson Plan on Educational Achievement of Iranian EFL Teachers' Attitudes. International Journal of Foreign Language Teaching \& Research. Volume 3, Issue 5 25-31.

Sesiorina, S. (2014). The Analysis of sTeachers' Lesson Plan in Implementing Theme-Based Instruction for Teaching English to Young Learners. Journal of English and Education, 2(1), 84-95 